\title{
Functional independence measure in patients with intermittent claudication
}

\author{
Medida de independência funcional em pacientes com claudicação intermitente \\ Medida de independencia funcional en pacientes con claudicación intermitente
}

Caroline Shihara de Assis ${ }^{1}$, Letícia de Carvalho Batista ${ }^{1}$, Nelson Wolosker², Antonio Eduardo Zerati ${ }^{2}$, Rita de Cassia Gengo e Silva ${ }^{3}$

\author{
${ }^{1}$ Universidade de São Paulo, Escola de \\ Enfermagem, São Paulo, SP, Brazil. \\ ${ }^{2}$ Universidade de São Paulo, Faculdade de \\ Medicina, Hospital das Clínicas, Ambulatório de \\ Claudicação, São Paulo, SP, Brazil. \\ ${ }^{3}$ Universidade de São Paulo, Escola de \\ Enfermagem, Departamento de Enfermagem \\ Médico-Cirúrgica, São Paulo, SP, Brazil.
}

\begin{abstract}
Objective: of this study were to evaluate the functional independence of patients with intermittent claudication and to verify its association with sociodemographic and clinical variables, walking ability and physical activity level. Method: This was a descriptive, exploratory, cross-sectional study with a quantitative approach. Fifty participants (66.4 years; $68 \%$ male) were recruited from Claudication Unit of a tertiary hospital. Functional Independence Measure were used to evaluate functional incapacity; the Baltimore Activity Scale, to estimate the physical activity level and the Walking Impairement Questionnaire, the walking ability. Results: Participants had complete functional independence (124.8 $\pm 2.0)$, low levels of physical activity $(4.2 \pm 2.0)$, and impairment of walking ability; the worst performance was found in walking velocity domain $(21.2 \pm 16.4)$. The functional independence score was associated with physical activity $(\mathrm{r}=0,402)$ and walking ability scores (distance, $r=0,485$; speed, $r=0,463$; stairs, $r=0,337$ ). Conclusion: In conclusion, the level of functionality is associated with functional capacity in these patients.
\end{abstract}

\section{DESCRIPTORS}

Peripheral Arterial Disease; Intermittent Claudication; Walking; Activities of Daily Living; Nursing. 


\section{INTRODUCTION}

Intermittent claudication (IC) is a major symptom of obstructive peripheral arterial disease (OPAD), which is recognized as an important public health problem worldwide $^{(1)}$. Both, symptomatic (IC) and asymptomatic OPAD are related with increased morbidity, mortality and a lower quality of life $\mathrm{f}^{(1,2)}$. In Brazil, its prevalence is $10.5 \%$ in the population over 18 years of age, and $21.6 \%$ in individuals over 60 years old ${ }^{(3)}$.

It characteristically affects the lower limbs and manifests as calf pain that is triggered by exercise and relieved by rest ${ }^{(1)}$. Several studies have shown that the functional capacity of patients with IC is reduced ${ }^{(3-5)}$. This evaluation can be performed by determining the walking ability and/ or physical activity level. With that aim, direct measurements are obtained, such as the treadmill test or the sixminute walk test ${ }^{(6)}$, or indirect measurements, such as the use of scales that measure the distance the patient is able to walk without triggering the symptom, or scales that determine how often the patient performs physical activities in daily life ${ }^{(7,8)}$.

The relationship between the loss of functional capacity, whether that is a reduced level of physical activity or reduced walking ability, and the ability to perform activities of daily living has not been established in this group of patients. Considering that nurses play an important role in research, planning and implementation of actions regarding the ability of people to perform daily activities, and that they represent an essential component of quality of life ${ }^{(9)}$, it is important to investigate whether impairment of functional capacity is related to the ability to perform activities of daily living.

The objectives of this study were to evaluate the functional independence of patients with IC, and the association of functional independence with sociodemographic and clinical variables, walking ability and level of physical activity.

\section{METHOD}

This was a descriptive, exploratory, cross-sectional study with a quantitative approach, with data collected from December/2013 to May/2014, in the Claudication Clinic at the Clinical Hospital, Medical School, University of São Paulo. This study is part of a larger project, which was approved by the Research Ethics Committee at School of Nursing, Universidade de São Paulo (protocol 403.3067; CAAE: 19282613.0.0000.5392).

Regarding the sample, the study design was intended to study all eligible patients. However, due to the dynamic of the clinic, that was not possible (working hours and patient flow - patients in the claudication group only had weekly appointments in the morning, the entry and exit of patients for medical consultations was more rapid than the ability of the authors to perform the evaluations that were relevant to the study). Therefore, the convenience sample consisted of patients of both genders diagnosed with lower limb IC, absence or reduction of arterial pulses, ankle brachial index
$(\mathrm{ABI})<0.9$ in the symptomatic limb, and over 18 years of age. We excluded patients in the postoperative period (up to six months), those who had suffered significant traumatic injuries in the six months prior to the study, those with associated neuromuscular and orthopedic diseases, and individuals who had been previously undergone any type of amputation. The exclusion criteria took into account conditions that could compromise the patients' functional ability for reasons other than claudication.

We collected demographic (gender, age and education) and clinical (time since the IC diagnosis and comorbidities) data by means of chart review and patient interviews. We used the Functional Independence Measure (FIM) ${ }^{(10)}$ to evaluate functional disability; the Baltimore Activity Scale for Intermittent Claudication (BASIC), ${ }^{(7)}$ and the Walking Impairment Questionnaire (WIQ) ${ }^{(8)}$ to estimate the level of physical activity and walking ability, respectively.

\section{Functional Independence Measure (FIM) $)^{(10,11)}$}

This is an instrument that evaluates the inability of patients with functional restrictions of various causes; it quantitatively evaluates the care demand of a person for performing motor and cognitive tasks of daily living. The validation of the Brazilian version was published in 2004 . It must be administered by means of interviews with the patient and/or caregiver. In the present study, the FIM was always applied to the patient.

The FIM contains 18 items, grouped into six dimensions: self-care, locomotion, transfers, communication, sphincter control and social cognition. Each item can be scored 1-7, corresponding to complete dependence and complete independence, respectively. Each dimension is analyzed by the sum of the items that comprise it. The total FIM score is the sum of the scores for each dimension, and can range between 18-126 points. Dependence levels are classified according to the total FIM score: 18: complete dependence; 19-60: modified dependence (assistance for up to $50 \%$ of tasks); 61-103: modified dependence (assistance for up to 25\% of tasks); and 104-126: complete/ modified independence.

\section{Baltimore Activity Scale for Intermittent Claudication (BASIC) $^{(7)}$}

This scale was developed to evaluate physical activity exclusively in patients with OPAD. Brazilian researchers ${ }^{(7)}$ found levels of reliability ranging from moderate to good in patients with IC.

The BASIC contains five questions related to symptom development, the patient's ability to walk before the onset of pain, attitudes adopted because of the emergence of the symptom, walking speed, and the ability to go up and down hills and stairs.

Each question has three possible responses, which correspond to 0,1 , and 2 points - in that order. The total score is the sum of the scores for each question, ranging from 0 - 10 points. The higher the total score, the greater the level of daily physical activity. 


\section{WALKING IMPAIRMENT QuestionNAIRE (WIQ) ${ }^{(8)}$}

This instrument is used to evaluate the walking ability of IC patients. The version that was translated and validated into Portuguese was published in 2009. It covers aspects related to the month before taking the survey, and consists of three domains: walking distance, walking speed and stair climbing.

It has seven initial questions, which aim to make the differential diagnosis of IC with other diseases that cause lower limb pain, followed by questions that evaluate the three domains. In these questions, the patient must point out the degree of difficulty to walk increasing distances at increasing speeds and climb up stairs. The degree of difficulty is measured by a 5 -point Likert scale, where $0=$ unable; 1 = much difficulty; 2 = some difficulty; 3 = slight difficulty; and $4=$ none.

For each domain, the points assigned to the items by the patient are multiplied by predetermined weights. The products of each domain are added together and divided by the maximum possible score for each domain to obtain a percentage score, which can range from 0 (representing the inability to perform the tasks) to 100 (representing no difficulty performing the task). For example, the walking speed domain consists of four items, whose score is multiplied by $1.5 ; 2 ; 3$ and 5 , respectively. Considering the maximum possible score for each item (4), the maximum possible score for that domain is 46 . Thereby, the sum of the products of the domain items (score assigned by the patient $\mathrm{x}$ weight of the item) is divided by 46 and multiplied by 100 to yield the percentage score.

The sociodemographic and clinical characteristics, functional independence measure, level of physical activity and walking ability were analyzed using descriptive statistics. The reliability of the scales was estimated by Cronbach's alpha. To investigate the association between the FIM, age, disease onset time, BASIC scores, and WIQ domains, the Spearman's correlation test was used; the FIM association with gender and comorbidities was investigated using the Mann-Whitney test, and the FIM association with education was investigated using the Jonckheere-Terpstra test. The significance level was $5 \%$.

\section{RESULTS}

\section{SOCIODEMOGRAPHIC AND CLINICAL CHARACTERISTICS}

The study included 50 consecutive patients with a mean age of 66.4 years $(\mathrm{SD}=10.2) ; 68 \%(\mathrm{n}=34)$ were male, $80 \%$ $(n=40)$ had complete or incomplete primary education. They had an OPAD diagnosis for 8.6 years $(\mathrm{SD}=8.5) ; 50 \%$ $(\mathrm{n}=25)$ had diabetes mellitus and $68 \%(\mathrm{n}=34)$ had arterial hypertension. Other comorbidities, such as atherosclerotic diseases, were less frequent than $20 \%$.

The mean activity score as measured by the BASIC was $4.2(\mathrm{SD}=2.0)$, ranging from $0-8$. Walking ability, as measured by the WIQ, had a mean score in the walking distance domain of $22.3(\mathrm{SD}=24.4)$, ranging from $0.5-89.3$; in the walking speed domain, the mean score was $21.2(\mathrm{SD}=$ 16.4), ranging from 0 - 60.9; in the stair climbing domain, the mean score was $34.6(\mathrm{SD}=29.1)$ with a minimum score of 0 and a maximum of 100 . The WIQ domains were found to show good reliability estimates (distance $=0.817$; speed $=0.808$; stairs $=0.876)$, whereas the same was not true for the BASIC (Cronbach's alpha $=0.254)$.

\section{FUnCTIONAL INDEPENDENCE MEASURE}

The lowest scores were assigned to the items in the communication and social cognition dimensions. The lowest mean score was observed in the item memory. Table 1 shows the total score and the score assigned to the MIF dimensions. The scale showed a good reliability estimate $($ Cronbach's alpha $=0.771)$.

Table 1 - FIM scores in patients with intermittent claudication. São Paulo, SP, Brazil, 2014.

\begin{tabular}{lccccccc}
\hline \multirow{2}{*}{ Dimension } & \multicolumn{5}{c}{ Domain - Motor Function } \\
\cline { 2 - 8 } & $\begin{array}{c}\text { Possible } \\
\text { range }\end{array}$ & $\begin{array}{c}\text { Observed } \\
\text { range }\end{array}$ & Mean & $\begin{array}{c}\text { Standard } \\
\text { deviation }\end{array}$ & Min Max \\
\hline 1 Self-care & $6-42$ & $39-42$ & 41.9 & 0.5 & 39.0 & 42.0 \\
2 Sphincter control & $2-14$ & $13-14$ & 13.9 & 0.3 & 13 & 14 \\
3 Transfers & $3-21$ & $19-21$ & 20.8 & 0.6 & 19 & 21 \\
4 Locomotion & $2-14$ & $12-14$ & 13.8 & 0.6 & 12 & 14 \\
Domain Scores & $13-91$ & $83-91$ & 90.3 & 1.6 & 83 & 91 \\
\hline \multirow{5}{*}{ Dimension } & Domain - Cognitive Function \\
\cline { 2 - 9 } & Possible & Observed & Mean & $\begin{array}{c}\text { Standard } \\
\text { deviation }\end{array}$ & Min & Max \\
\hline 5 Communication & $2-14$ & $12-14$ & 13.9 & 0.4 & 12 & 14 \\
6 Social Cognition & $3-21$ & $19-21$ & 20.6 & 0.7 & 19 & 21 \\
Domain scores & $5-35$ & $32-35$ & 34.5 & 0.8 & 32 & 35 \\
\hline Total FIM & $\mathbf{1 8 - 1 2 6}$ & $\mathbf{1 1 7 - 1 2 6}$ & $\mathbf{1 2 4 . 8}$ & $\mathbf{2 . 0}$ & $\mathbf{1 1 7}$ & $\mathbf{1 2 6}$ \\
\hline
\end{tabular}

Legend: FIM - Functional Independence Measure; Min - minimum; Max - maximum

\section{FUNCTIONAL INDEPENDENCE AND SOCIODEMOGRAPHIC AND CLINICAL VARIABLES}

No statistically significant association was found between the sociodemographic and clinical variables with the total FIM score.

\section{FUNCTIONAL INDEPENDENCE, LEVEL OF PHYSICAL ACTIVITY AND WALKING ABILITY}

The correlation between the BASIC scores and the WIQ domains with the FIM scores are shown in Table 2.

Table 2 - Correlation between the level of physical activity (BA$\mathrm{SIC})$, walking ability (WIQ), and functional independence (FIM) in patients with intermittent claudication. São Paulo, SP, Brazil, 2014.

\begin{tabular}{lll}
\hline & FIM & p-value* \\
\hline BASIC & 0.402 & 0.004 \\
WIQ - walking distance & 0.485 & $<0.001$ \\
WIQ - walking speed & 0.463 & 0.001 \\
WIQ - stair climbing & 0.337 & 0.017 \\
\hline
\end{tabular}

Legend: FIM: Functional Independence Measure; BASIC: Baltimore Activity Scale for Intermittent Claudication; WIQ: Walking Impairment Questionnaire; * Spearman's correlation Test 


\section{DISCUSSION}

This study evaluated patients with IC in terms of their care demand related to motor and cognitive functions of daily life, using the FIM.

The Functional Independence Measure is an instrument that can be used for patients with restrictions of different etiologies $^{(10)}$. Our results suggest that the IC patients have complete or modified functional independence (FIM = 124.8), namely, they do not need help to perform their activities of daily living.

It was expected that participants with more comorbidities would have lower total MIF scores, which did not occur. It is possible that this finding can be attributed to the low variability of the scores and the MIF items. Nevertheless, the scale showed good reliability estimates in this sample.

The mean age of participants was 66.4 years. It is known that the prevalence of OPAD, and therefore IC, increases with age ${ }^{(12)}$. Researchers who evaluated the functional independence of ambulatory or hospitalized elderly obtained similar results to ours in relation to the total FIM score ${ }^{(13-15)}$. A study ${ }^{(15)}$ that evaluated elderly who were participating in a living group confirms our findings, although they observed lower scores for such functions in hospitalized oldest old adults $^{(14)}$. In certain research reports, the variability of the FIM scores is similar to that observed in the present study, whereas in others the variation is higher ${ }^{(16,17)}$. It should be noted that there are no studies that have evaluated the FIM in patients with IC.

Among our participants there was a predominance of males. This result was expected because there is a higher prevalence of PAD among men ${ }^{(12)}$. We cannot state, however, that the greater number of male participants contributed to the FIM results, since there are controversies in the literature on this topic. Among patients of a geriatric outpatient clinic, it was found that the FIM scores were significantly higher among men ${ }^{(13)}$. However, studies in other populations showed that the FIM scores were higher among women ${ }^{(18,19)}$.

The most frequent comorbidities were diabetes and arterial hypertension. Both are considered major contributing factors for the development of OPAD. According to the I Brazilian Position Statement on Arterial Hypertension and Diabetes Mellitus ${ }^{(2)}$, high blood pressure and diabetes are among the leading causes of OPAD; the risk of developing this disease is higher among diabetic men compared to non-diabetics. A Brazilian study showed that the self-reported prevalence of diabetes and hypertension in patients with OPAD were $61.5 \%$ and $55.7 \%$, respectively ${ }^{(21)}$.

We observed that our participants had low levels of physical activity. Studies support these findings in patients with $\mathrm{IC}^{(22)}$. A study with 150 patients with IC, aged between 30 and 80 years, quantified the level of physical activity using the BASIC in these patients and found that the mean BASIC score was $4.2(1.9)^{(22)}$.

The mean BASIC score showed a statistically significant association with the total MIF scores. Although the participants of this study had functional independence, the correlation test showed that the higher the level of physical activity, the greater the level of functional independence.

Although there are similar findings in the literature ${ }^{(5,22)}$, the results of the present study need to be interpreted with caution. The reliability of the BASIC in our sample did not obtain an acceptable level $(<0.70)$. This can be attributed to the sample size and number of items in the instrument. It is known that the smaller the number of items of an instrument, the greater the estimated variance of responses, and thereby the lower its reliability estimate ${ }^{(23)}$.

A study that analyzed the correlation between the level of physical activity, as estimated by the BASIC, and the level obtained by a pedometer in patients with IC showed a statistically significant correlation between the score of the scale and level of weekly physical activity, as measured by the number of steps ${ }^{(22)}$. Another study carried out by Brazilian researchers noted that the interrater agreement ranged from 0.43 to 0.85 , depending on the item of the scale, and the scale agreement coefficient was greater for women and young patients ${ }^{(7)}$.

Regarding the WIQ, it was found that all domains were significantly associated with the total FIM score. This indicates that the greater the walking ability, the greater the functional independence. Although there was a wide variation in scores (standard deviations close to the mean values), the reliability estimates were good for all WIQ domains $(>0.80)$.

A study comparing the results of direct evaluation of walking ability with the WIQ results indicated that this is a valid instrument to detect the improvement or decline of this ability in patients with $\mathrm{IC}^{(24)}$. A Brazilian study that evaluated 500 patients with IC found similar results regarding the outcomes of functional ability, as measured directly or indirectly ${ }^{(25)}$. Researchers also found that the WIQquestions related to difficulty walking short distances at a low speed are predictive of total distances and symptom onset in patients with $\mathrm{IC}^{(26)}$.

The results of this study suggest that patients with IC should be encouraged to have a recommended level of physical activity, in order to maintain their functional independence to perform motor and cognitive functions of daily living. It is possible that interventions aimed at improving the walking ability positively influence functional independence. However, this hypothesis needs to be confirmed.

This study has limitations. The convenience sample and the cross-sectional design compromise the external validity, and therefore the generalizability of these results. Although some of the instruments used are self-administered, all instruments were read to participants during data collection, given their difficulty reading and understanding. The fact that it was a single-center study in a high complexity service may have contributed to the inclusion of patients with more severe clinical status, and therefore their levels of physical activity and walking ability may be lower. We suggest that further studies should be conducted to confirm our results.

\section{CONCLUSION}

Patients with IC treated in a specialized and high complexity clinic have complete independence in performing 
motor and cognitive activities of daily living. The lowest FIM scores were observed in communication and social cognition dimensions, which include: understanding, ex- pression, social interaction, problem solving and memory. Functional independence is associated with higher levels of physical activity and greater walking ability.

\section{RESUMO}

Objetivo: Avaliar a independência funcional de pacientes com claudicação intermitente e verificar sua associação com variáveis sociodemográficas e clínicas, capacidade de locomoção e nível de atividade física. Método: Estudo descritivo, exploratório, transversal, com abordagem quantitativa, realizado com cinquenta participantes (66,4 anos; $68 \%$ homens) no Ambulatório de Claudicação do Hospital das Clínicas da Faculdade de Medicina da Universidade de São Paulo. A Medida de Independência Funcional foi utlizada para avaliar a incapacidade funcional; a Baltimore Activity Scale para estimar o nível de atividade física e o Walking Impairement Questionnaire, a capacidade de locomoção. Resultados: Observou-se independência funcional completa $(124,8 \pm 2,0)$, baixo nível de atividade física $(4,2 \pm 2,0)$ e comprometimento na capacidade de locomoção, com pior desempenho no domínio velocidade de caminhada $(21,2 \pm 16,4)$. $\mathrm{O}$ escore da medida de independência funcional associou-se com os escores das escalas que estimam nível de atividade física ( $\mathrm{r}=0,402)$ e capacidade de locomoção (distância, r=0,485; velocidade, $r=0,463$; escada, r=0,337). Conclusão: $\mathrm{O}$ grau de funcionalidade está associado com a capacidade funcional desses pacientes.

\section{DESCRITORES}

Doença Arterial Periférica; Claudicação Intermitente; Caminhada; Atividades Cotidianas; Enfermagem.

\section{RESUMEN}

Objetivo: Evaluar la independencia funcional de pacientes con claudicación intermitente y verificar su asociación con variables sociodemográficas y clínicas, capacidad de locomoción y nivel de actividad física. Método: Estudio descriptivo, exploratorio, transversal, con abordaje cuantitativo, llevado a cabo con cincuenta participantes (66,4 años; 68\% hombres) en el Ambulatorio de Claudicación del Hospital de Clínicas de la Facultad de Medicina de la Universidad de São Paulo. La Medida de Independencia Funcional fue utilizada para valorar la incapacidad funcional; la Baltimore Activity Scale para estimar el nivel de actividad física; y el Walking Impairement Questionnaire, la capacidad de locomoción. Resultados: Se advirtió independencia funcional completa $(124,8 \pm 2,0)$, bajo nivel de actividad física $(4,2 \pm 2,0)$ y compromiso de la capacidad de locomoción, con peor desempeño en el dominio de la velocidad de caminar $(21,2 \pm 16,4)$. El puntaje de la medida de independencia funcional se asoció con los puntajes de las escalas que estiman nivel de actividad física $(r=0,402)$ y capacidad de locomoción (distancia, $r=0,485$; velocidad, $r=0,463$; escalera, r=0,337). Conclusión: El grado de funcionalidad está asociado con la capacidad funcional de esos pacientes.

\section{DESCRIPTORES}

Enfermedad Arterial Periférica; Claudicación Intermitente; Caminata; Actividades Cotidianas; Enfermería.

\section{REFERENCES}

1. Go AS, Mozaffarian D, Roger VL, Benjamin EJ, Berry JD, Blaha MJ, et al. Heart disease and stroke statistics-2014 update: a report from the American Heart Association. Circulation. 2013;129(3):e28-e292.

2. Ahimastos AA, Walker PJ, Askew C, Leicht A, Pappas E, Blombery P, et al. Effect of ramipril on walking times and quality of life among patients with peripheral artery disease and intermittent claudication: a randomized controlled trial. JAMA. 2013;309(5):453-60.

3. Barbosa JPAS, Berenguer MF, Rodrigues LBCC, Miranda AS, Gobbo LA, Cucato GG, et al. Associação de comorbidades e hábitos não saudáveis com a capacidade de caminhada em pacientes com claudicação intermitente. Rev Bras Educ Fís Esporte. 2011;25(2):277-84.

4. Fakhry F, Spronk S, Ridder M, den Hoed PT, Hunink MG. Long-term effects of structured home-based exercise program on functional capacity and quality of life in patients with intermittent claudication. Arch Phys Med Rehabil. 2011;92(7):1066-73.

5. Barbosa JPAS, Henriques PM, Barros MVG, Wolosker N, Ritti-Dias RM. Nível de atividade física em indivíduos com doença arterial periférica: uma revisão sistemática. J Vasc Bras. 2012;11(1):22-8.

6. França MA, Lima TM, Santana FS, Lins-Filho OL, Cucato GG, Cardoso-Júnior CG, et al. Relationship between the performance of 6 minutes walk test and treadmill test in patients with intermittent claudication of lower limbs. J Vasc Bras. 2012;11(4):263-8.

7. Barbosa JPS, Lima RA, Gardner AW, Barros MV, Wolosker N, Ritti-Dias RM. Reliability of the Baltimore Activity Scale Questionnaire for Intermittent Claudication. Angiology. 2012;63(4):254-8.

8. Ritti-Dias RM, Gobbo LA, Cucato GG, Wolosker N, Jacob Filho W, Santarém JM, et al . Tradução e validação do Walking Impairment Questionnaire em brasileiros com claudicação intermitente. Arq Bras Cardiol. 2009;92(2):143-9.

9. Fangel LMV, Panobianco MS, Kebbe LM, Almeida AM, Gozzo TO. Qualify of life and daily activities performance after breast cancer treatment. Acta Paul Enferm. 2013;26(1):93-100.

10. Riberto M, Miyazaki MH, Jucá SSH, Sakamoto H, Pinto PPN, et al. Validação da versão brasileira da Medida de Independência Funcional. Acta Fisiatr. 2004;1(2):72-6.

11. Ricci NA, Kubota MT, Cordeiro RC. Agreement between observations on the functional capacity of home care elderly patients. Rev Saúde Pública. 2005;39(4):655-62.

12. Makdisse M, Pereira AC, Brasill DP, Borges JL, Machado-Coelho GLL, Krieger JE, et al. Prevalência e fatores de risco associados à doença arterial periférica no projeto corações do Brasil. Arq Bras Cardiol. 2008;91(6):402-14. 
13. Sposito G, D’Elboux MJ, Neri AL, Guariento ME. A satisfação com a vida e a funcionalidade em idosos atendidos em um ambulatório de geriatria. Ciênc Saúde Coletiva. 2013;18(12):3475-82.

14. Lourenço TM, Lenardt MH, Kletemberg DF, Seima MD, Carneiro NHK. Independência funcional em idosos longevos na admissão hospitalar. Texto Contexto Enferm. 2014;23(3):673-9.

15. Aragoni J, Hernadez SSS, Marchesini BL, Simas J, Mazo GZ. Independência funcional e estágios de mudança de comportamento para atividade física de idosos participantes em grupos de convivência. R Bras Qual Vida. 2013;5(2):31-40.

16. Yamada JT, Nishihira SN, Torturela M. Aplicação da Medida de Independência Funcional na prática do autocuidado em uma unidade de internação geriátrica. RBCEH Rev Bras Ciênc Env Hum. 2009;6(2):254-63.

17. Murakami L, Scattolin F. Evaluation of functional independence and quality of life in institutionalized elderly. Rev Med Hered. 2010;21(1):18-26.

18. Cox PS, Williams SKP, Weaver SR. Life after lower extremity amputation in diabetics. West Indian Med J. 2011;60(5):536-40.

19. Mizrahi EH, Arad M, Fleissig Y, Adunsky A. Gender differences in functional outcome of elderly hip fracture patients. Geriatr Gerontol Int. 2014;14(4):845-50.

20. Alessi A, Bonfim AV, Brandão AA, Feitosa A, Amodeo C, Alves CR, et al; Sociedade Brasileira de Cardiologia; Departamento de Hipertensão Arterial. I Posicionamento Brasileiro em Hipertensão Arterial e Diabetes Mellitus. Arq Bras Cardiol. 2013;100(6):491-501.

21. Diniz JN, Pires RCCP. Percepção da doença arterial obstrutiva periférica por pacientes classe I ou II de Fontaine de um Programa de Saúde da Família. J Vasc Bras. 2010;9(3):124-130.

22. Lopes PR, Barbosa JPAS, Farah BQ, Chehuen MR, Cucato GG, Wolosker N, et al . Relação entre o nível de atividade física estimado pelo Baltimore Activity Scale for Intermittent Claudication e a pedometria em pacientes com claudicação intermitente. J Vasc Bras. 2013;12(3):187-92.

23. Maroco J, Garcia-Marques T. Qual a fiabilidade do alfa de Cronbach? Questões antigas e soluções modernas? Lab Psicol. 2006;4(1):65-90.

24. Nicolaï SP, Kruidenier LM, Rouwet EV, Graffius K, Prins MH, Teijink JA. The walking impairment questionnaire: An effective tool to assess the effect of treatment in patients with intermittent claudication. J Vasc Surg. 2009;50(1):89-94.

25. Cucato GG, Zerati AE, Chehuen MR, Ritti-Dias RM, Saez G, Ragazzo L, et al. Comparação entre os métodos subjetivos e objetivo para avaliação da capacidade funcional durante tratamento clínico em pacientes com claudicação intermitente. Einstein (São Paulo). 2013;11(4):495-9.

26. Quintella FB, Barbosa JPAS, Grizzo GC, Chehuen MR, Gobbo AL, Wolosker N, et al Predictors of walking capacity in peripheral arterial disease patients. Clinics. 2013; 68(4):537-41.

Financial support: Conselho Nacional de Desenvolvimento Científico e Tecnológico - CNPq. 